\title{
Shear force and torsion in reinforced concrete beam elements: theoretical analysis based on Brazilian Standard Code ABNT NBR 6118:2007
}

\section{Solicitações tangenciais em elementos lineares de concreto armado: análise teórica baseada na ABNT NBR 6118:2007}
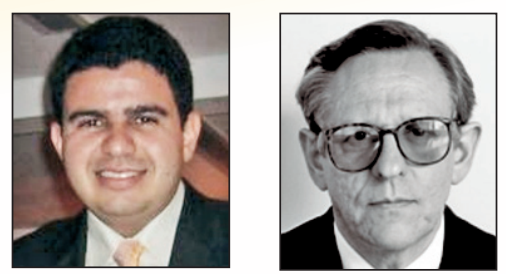

R. BARROS a barrosrn@sc.usp.br

J.S. GIONGO b jsgiongo@sc.usp.br

\begin{abstract}
Reinforced concrete beam elements are submitted to applicable loads along their life cycle that cause shear and torsion. These elements may be subject to only shear, pure torsion or both, torsion and shear combined. The Brazilian Standard Code ABNT NBR 6118:2007 [1] fixes conditions to calculate the transverse reinforcement area in beam reinforced concrete elements, using two design models, based on the strut and tie analogy model, first studied by Mörsch [2]. The strut angle $\theta$ (theta) can be considered constant and equal to $45^{\circ}$ (Model I), or varying between $30^{\circ}$ and $45^{\circ}$ (Model II). In the case of transversal ties (stirrups), the variation of angle $\alpha$ (alpha) is between $45^{\circ}$ and $90^{\circ}$. When the equilibrium torsion is required, a resistant model based on space truss with hollow section is considered. The space truss admits an inclination angle $\theta$ between $30^{\circ}$ and $45^{\circ}$, in accordance with beam elements subjected to shear. This paper presents a theoretical study of models I and II for combined shear and torsion, in which ranges the geometry and intensity of action in reinforced concrete beams, aimed to verify the consumption of transverse reinforcement in accordance with the calculation model adopted As the strut angle on model II ranges from $30^{\circ}$ to $45^{\circ}$, transverse reinforcement area (Asw) decreases, and total reinforcement area, which includes longitudinal torsion reinforcement (Asf), increases. It appears that, when considering model II with strut angle above $40^{\circ}$, under shear only, transverse reinforcement area increases $22 \%$ compared to values obtained using model I.
\end{abstract}

Keywords: reinforced concrete, calculation models, shear force, torsion.

\section{Resumo}

Elementos lineares em concreto armado estão sujeitos a solicitações tangenciais ao longo de sua vida útil. Tais solicitações são oriundas de dois esforços solicitantes: força cortante e momento torçor, podendo haver ação combinada destes esforços. A ABNT NBR 6118:2007 [1] fixa as condições para o cálculo da área de armadura transversal para absorver as tensões provenientes da força cortante, admitindo dois modelos teóricos baseados na analogia de treliça de banzos paralelos, inicialmente estudada por Mörsch [2]. $O$ ângulo $\theta$ de inclinação da biela de compressão pode ser considerado constante e igual a $45^{\circ}$ (Modelo I) ou variando entre $30^{\circ} \mathrm{e} 45^{\circ}$ (modelo II). Quando o momento torçor é necessário ao equilíbrio da estrutura, considera-se um modelo resistente constituído por uma treliça espacial de seção vazada. Essa treliça admite ângulos de inclinação variando entre $30^{\circ} \mathrm{e} 45^{\circ}$ em concordância com o modelo resistente à força cortante. Apresenta-se um estudo teórico a respeito dos modelos de cálculo I e II para força cortante combinados com a ação de momento torçor, no qual variaram-se a geometria e a intensidade das ações em vigas de concreto armado, cujo objetivo foi verificar o consumo de armadura transversal em função do modelo de cálculo adotado. À medida que o ângulo $\theta$ diminui no modelo de cálculo II, tem-se redução na área de armadura transversal (Asw) e aumento na área total que considera a armadura longitudinal de torção (Asl). Verifica-se ainda que, ao considerar o modelo de cálculo II com ângulo $\theta$ acima de $40^{\circ}$ quando da atuação apenas da força cortante, tem-se aumento em até $22 \%$ na área de armadura transversal, quando comparada com a armadura obtida utilizando o modelo de cálculo I.

Palavras-chave: concreto armado, modelo de cálculo, força cortante, momento torçor.

Doutorando em Engenharia de Estruturas, Departamento de Engenharia de Estruturas, Escola de Engenharia de São Carlos, Universidade de São Paulo, barrosrn@sc.usp.br, Av. Trabalhador São-carlense, 400, CEP: 13566-590, São Carlos-SP, Brasil;

Professor Doutor, Departamento de Engenharia de Estruturas, Escola de Engenharia de São Carlos, Universidade de São Paulo, jsgiongo@sc.usp.br, Av. Trabalhador Sãocarlense, 400, CEP: 13566-590, São Carlos-SP, Brasil. 


\section{Introduction}

ABNT NBR 6118:2007 [1] sets conditions for the verification of reinforced concrete beam elements subjected to shear force, possibly combined with other action effects, allowing two calculation models. Such models are based on the parallel chord truss analogy, initially studied by Mörsch [2], in which the angle $\theta$ of inclination of the strut can be considered constant and equal to $45^{\circ}$ (model I) or ranging from $30^{\circ}$ to $45^{\circ}$ (model II). The transverse reinforcement may present inclination between $45^{\circ}$ and $90^{\circ}$, and it is usually used in ties projects with an inclination of $90^{\circ}$.

The aim of this paper is to present the analysis of the percentage differences obtained from the values of transverse reinforcement areas for reinforced concrete beams related to calculation models I and II. The method consists of theoretical analyzes based on the equations of the calculation models presented in the Brazilian Standard Code ABNT NBR 6118:2007 [1]. The characteristics of each calculation model and a comparative study of the main parameters that compose each model are presented. In this respect, analyzes of the calculation results of the reinforcement areas derived from the isolated action of shear force and torsion, as well as their combined action, are presented.

\subsection{Initial studies}

The classical calculation model of reinforced concrete beam elements submitted to shear force is based on the classic truss of Mörsch [2], which considers the beam behavior analogous to an isostatic truss, in which the upper and lower chords are parallel to each other, and represented respectively by the region of the compression concrete and the longitudinal tensile reinforcement bars of the beam.

Between the chords there are compression concrete struts inclined at $45^{\circ}$ degrees to the longitudinal axis of the beam, and a tie inclined at an angle $\alpha$ which can vary from $45^{\circ}$ to $90^{\circ}$, located transversely to the concrete cracks.

In the truss model, the loads in the compression strut and tie increase in intensity from the center of the beam towards the support conditions, where the shear force presents its maximum value. By contrast, the forces on the compression chord and longitudinal tensile reinforcement bars reach their peak in regions near the middle of the span. Tests conducted by Leonhardt \& Mönnig [3] found that the measured stresses in the transverse reinforcement were lower than those expected in the design, implying that the theoretical model of classical truss led to high values of transverse reinforcement. The observations made by Leonhardt \& Mönnig [3] are due to several factors. The first is that the compression chord is relatively inclined when compared to the tensile chord, allowing a direct absorption of a portion of the shear force on the concrete. Due to this inclination, the $\mathrm{R}_{\mathrm{st}}$ load acting on the longitudinal reinforcement is greater than the $\mathrm{R}_{\mathrm{cc}}$ load acting on the compression chord.

Regarding the diagonals, the cracks and the struts between them are variably inclined in relation to the longitudinal axis of the beam presenting inclinations lower than $45^{\circ}$.

The relative stress decrease in the transverse reinforcement is due to alternative schemes of shear force absorption developed with the truss. These schemes are the Arc effect, the interlocking aggregate effect and the dowel effect of the longitudinal reinforce- ment bars. Because of these alternative mechanisms, a $V_{c}$ value reduction of the shear force is considered. Its objective is to approximate the theoretical model to the actual model.

\section{Calculation models for shear force}

The use of calculation models I and II presented in the Brazilian Standard Code ABNT NBR 6118:2007 [1] are widely discussed. Mota \& Laranjeiras [4] concluded via electronic mailing list that calculation model I is not a particular case of calculation model II. Savaris \& Garcia [5] developed a study on the optimum angle to the strut and tie to achieve minimum consumption of the area of the transverse and longitudinal reinforcement bars. The researchers found that model I leads to a minimum consumption of the reinforcement if used with stirrups inclined between $55^{\circ}$ and $60^{\circ}$. However, the use of inclined stirrups is not often adopted because it requires greater care in detail and beams assemble during the construction stages.

Barros \& Giongo [6] stated a relation between the areas of the transverse reinforcement bars, obtained according to calculation models I and II, and it does not depend on the geometry of the structural element or the intensity of the actions.

The calculation models presented in the Brazilian Standard Code ABNT NBR 6118:2007 [1] to verify the safety of reinforced concrete beam elements subjected to shear force are similar in some situations. For both models, it is considered that all elements must have a minimum transverse reinforcement consisting of stirrups, which the minimal geometric rate $\left(\rho_{\text {swmin }}\right)$ depends on the average resistance to the tensile concrete and the characteristic resistance to the steel flow of the transverse reinforcement.

Both models permit stirrups with variable inclination ranging from $45^{\circ}$ to $90^{\circ}$, and stipulate a maximum value for the $V_{S d}$ design value of shear force. This value considers the resistance capacity of the compression strut, named $V_{\mathrm{Rd} 2}$, which its expression depends on each calculation model. This limitation intends to prevent that elements subjected to shear force are ruined due to a rupture of the compression strut concrete.

The expressions presented in the next items and presented in the Brazilian Standard Code ABNT NBR 6118:2007 [1] and follow the indications of the Model Code CEB-FIP [7]. These deductions can be found at Mangini [8].

\subsection{Calculation model I}

Calculation model I allows the compression struts to have constant $\theta$ inclination in relation to the longitudinal axis of the element with a value of $45^{\circ}$. Furthermore, it considers a $V_{c}$ reduction portion of the design shear resistance of $\mathrm{V}_{\mathrm{Rd} 3}$ due to the schemes used as an alternative to the truss schemes previously described. In cases of flexure and flexotraction in which the neutral axis crosses the section of the structural element, the $V_{c}$ portion equals $V_{c 0}$ and its value is constant and independent of the design value of shear force, $V_{\text {sd }}$. The concrete compression strut is verified through equation (1), and the calculation of the transverse reinforcement is given by equation (2).

$$
\mathrm{V}_{\mathrm{sd}} \leq \mathrm{V}_{\mathrm{Rd} 2}=0,27 \cdot\left(1-\mathrm{f}_{\mathrm{ck}} / 250\right) \cdot \mathrm{f}_{\mathrm{cd}} \cdot \mathrm{b}_{\mathrm{w}} \cdot \mathrm{d}
$$




$$
\mathrm{V}_{\mathrm{sw}}=\left(\frac{\mathrm{A}_{\mathrm{sw}}}{\mathrm{s}}\right) \cdot 0,9 \cdot \mathrm{d} \cdot \mathrm{f}_{\mathrm{ywd}} \cdot(\operatorname{sen} \alpha+\cos \alpha)
$$

Equations (3) and (4) present the safety criteria of the transverse reinforcement. In these equations, the value of $f_{c t d}$, which is the value for calculating the concrete resistance to the direct traction, is obtained according to the characteristic resistance to compression $\left(f_{c k}\right)$ in equation (5).

$\mathrm{V}_{\mathrm{sd}} \leq \mathrm{V}_{\mathrm{Rd} 3}=\mathrm{V}_{\mathrm{c}}+\mathrm{V}_{\mathrm{sw}}$

$\mathrm{V}_{\mathrm{c} 0}=0,6 \cdot \mathrm{f}_{\mathrm{ctd}} \cdot \mathrm{b}_{\mathrm{w}} \cdot \mathrm{d}$

$$
\mathrm{f}_{\mathrm{ctd}}=0,15 \cdot \sqrt[3]{\mathrm{f}_{\mathrm{ck}}^{2}}
$$

The Brazilian Standard Code ABNT NBR 6118:2007 [1] indicates that when the longitudinal tensile reinforcement bar is obtained considering the balance of loads in the normal cross-section to the axis of the structural element, the effects caused by the diagonal crack may be replaced, in the calculation, by the offset $\left(a_{\ell}\right)$ of force in the tensile chord diagram. The offset depends on the design value of shear force $\left(V_{s d}\right)$, the portion $\left(V_{c}\right)$, the effective depth ("d") of the structural element and the a angle of inclination of the stirrups. Although it is not explicit in the Standard, the value of $a_{p}$ must be limited to the value of the effective depth (d) of the element, and it is a required parameter for determining the final length of the longitudinal tensile reinforcement bars. It directly influences the consumption of the reinforced beam. One way to decrease the value of the offset in model I and, therefore, the length of the longitudinal reinforcement bars is to consider that the shear force is absorbed by the stirrups, which implies that the value of $V_{c}$ equals zero. This consideration leads to an increase in the area of the transverse reinforcement. But, as in a reinforced concrete beam the amount of steel in the longitudinal reinforcement is much higher than the volume of steel in the transverse reinforcement, the consumption of steel in the beam decreases.

\subsection{Calculation Model II}

For determining the area of the transverse reinforcement bars, the compression struts in calculation model II have variable inclination relative to the longitudinal axis of the beam, in the range $30^{\circ} \leq$ $\theta \leq 45^{\circ}$. This model assumes that the portion $V_{c}$ of reduction of the design shear resistance $\left(\mathrm{V}_{\mathrm{Rd} 3}\right)$ is variable due to the alternative schemes to the trusses. In this hypothesis, the $V_{c}$ portion depends on the design value of shear force $\left(\mathrm{V}_{\mathrm{Rd} 3}\right)$ and the design shear resistance $\left(V_{\mathrm{Rd} 2}\right)$. It differs from model $\mathrm{I}$, in which the value of $\mathrm{V}_{\mathrm{c}}$ is constant. The value of $V_{c}$ equals $V_{c 1}$ in flexure and flexotraction, in which the neutral axis crosses the section of the structural element. This value can be obtained through equation (6).

$$
\mathrm{V}_{\mathrm{c} 1}=\left(\frac{\mathrm{V}_{\mathrm{Rd} 2}-\mathrm{V}_{\mathrm{sd}}}{\mathrm{V}_{\mathrm{Rd} 2}-\mathrm{V}_{\mathrm{c} 0}}\right) \cdot \mathrm{V}_{\mathrm{c} 0}
$$

The previous expression was derived by linear interpolation, and the value of $V_{c 1}$ equals $V_{c 0}$ when the value of $V_{s d}$ equals $V_{c 0}$. Similarly, $V_{c 1}$ equals zero when the design value of shear force $V_{S d}$ equals the value of the design shear resistance $\left(\mathrm{V}_{\mathrm{Rd} 2}\right)$.

The design shear resistance in relation to the compression strut capacity is calculated through equation (7), and the calculation of the transverse reinforcement is based on equation (8). It is observed that when angle $\theta$ is $45^{\circ}$ in equation (7), this equation equals the design shear resistance equation obtained using calculation model I.

$$
\begin{aligned}
& \mathrm{V}_{\mathrm{sd}} \leq \mathrm{V}_{\mathrm{Rd} 2}=0,54 \cdot\left(1-\mathrm{f}_{\mathrm{ck}} / 250\right) \cdot \mathrm{f}_{\mathrm{cd}} \cdot \mathrm{b}_{\mathrm{w}} \cdot d \cdot \operatorname{sen}^{2} \theta \cdot(\operatorname{cotg} \alpha+\operatorname{cotg} \theta) \\
& \mathrm{V}_{\mathrm{sw}}=\left(\frac{\mathrm{A}_{\mathrm{sw}}}{\mathrm{s}}\right) \cdot 0,9 \cdot \mathrm{d} \cdot \mathrm{f}_{\mathrm{ywd}} \cdot(\cot g \alpha+\cot g \theta) \cdot \operatorname{sen} \alpha
\end{aligned}
$$

Considering the offset $\left(a_{\ell}\right)$ of the force in the tensile chords diagram for calculation model II, it depends on the value of the effective height ("d") of the structural element, the angle $\theta$ of inclination of the strut and the angle a of inclination of the stirups. The value of $a_{\ell}$ must be limited to the value of the effective height of the element. Thus, the less the value of angle $\theta$ of strut inclination is, the more the value of $a_{\ell}$ is. Consequently, the length of the longitudinal reinforcement bars is longer and the total consumption of steel in the analyzed beam tends to increase. Differently from calculation model I, considering that the shear force is absorbed by the stirrups does not influence the value of the offset or the consumption of the longitudinal reinforcement.

\section{Analysis result between calculation models I and II}

The main difference between the model calculations I and II proposed by the Brazilian Standard Code ABNT NBR 6118:2007 is the consideration of the angle $\theta$ as constant and equal to $45^{\circ}$ in model I, and ranging from $30^{\circ}$ to $45^{\circ}$ in Model II. For both models, the stirrups can have inclination a ranging from $45^{\circ}$ to $90^{\circ}$. For this study, the angle $\alpha$ is considered $90^{\circ}$, since this value is the most commonly used in structures because of the constructive ease. Another reason for using vertical stirrups is the inefficiency of inclined stirrups when there is load inversion, which occurs in areas subject to earthquakes. Both models allow the verification of the concrete compression strut, 
through the portion $\mathrm{V}_{\mathrm{Rd} 2}$ and subsequent calculation of the area of the transverse reinforcement $A_{s w}$. $A$ decrease in the design value is possible due to the truss additional mechanisms, previously presented in this study. This decrease is constant in model I for any design value, and in calculation model II, the decrease depends on the value of the design shear force $\left(\mathrm{V}_{\mathrm{Sd}}\right)$.

Thus, the first observation made is that in calculation model II, as the design force increases, $V_{c 1}$ force decreases, and equals zero when the design value of shear force $\mathrm{V}_{\mathrm{Sd}}$ is at its maximum, when it is equal to the resistance capacity of the compression strut, defined by $V_{\mathrm{Rd} 2}$. This resistance capacity is constant in calculation model I and variable in calculation model II, decreasing due to angle $\theta$ adopted in the latter. It is stated that this decrease occurs according to a relation that is independent of the geometry and the structural element design. By dividing equation (7) by equation (1), the relation between the design shear resistances $V_{\mathrm{Rd} 2}$ is obtained. It results in equation (9), which exclusively depends on the angle of inclination of the compression strut.

$$
\frac{\mathrm{V}_{\mathrm{Rd} 2, \mathrm{MII}}}{\mathrm{V}_{\mathrm{Rd} 2, \mathrm{MI}}}=\operatorname{sen}(2 \theta)
$$

Figure 1 shows the relation obtained through equation (9). According to Figure 1 , by adopting angle $\theta$ equal to $45^{\circ}$ in calculation model II, one obtains the same value for the $V_{\mathrm{Rd} 2}$ force when using calculation model I. However, as the inclination angle $\theta$ decreases, the value of $\mathrm{V}_{\mathrm{Rd} 2}$ force also decreases. Therefore, the resistance capacity of the strut decreases to $87 \%$ of $\mathrm{V}_{\mathrm{Rd} 2}$ value obtained through calculation model I when the minimum inclination $\theta$ equals $30^{\circ}$. Several practical examples presented in Barros \& Giongo [6] confirm these results.

Regarding the calculation of the transverse reinforcement area, two distinct comparisons are made. The first relates the results ob-

\section{Figure 1 - Relation between design shear resistance relative to compression strut $V_{R d 2}$, for design models I and II of ABNT NBR $6118: 2007$ (1)}

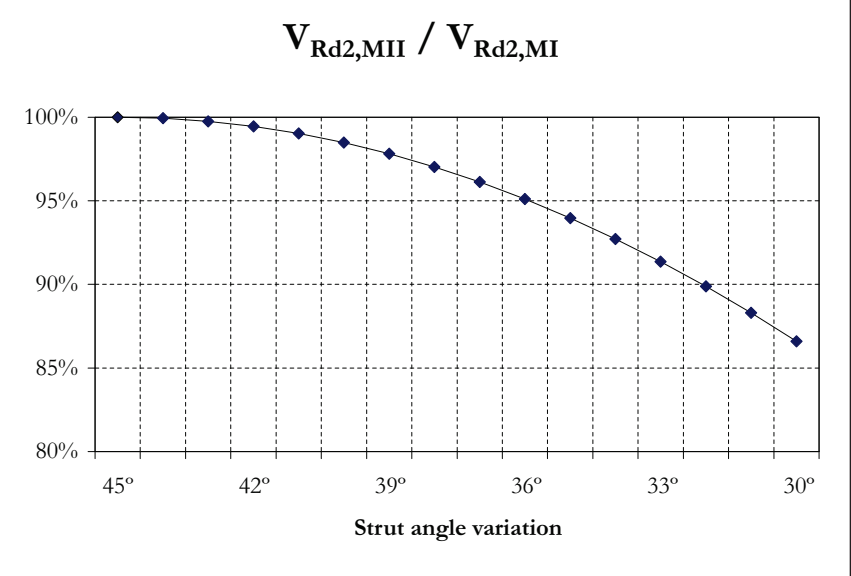

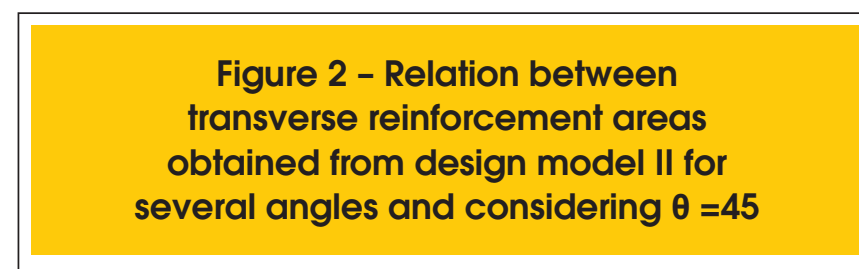

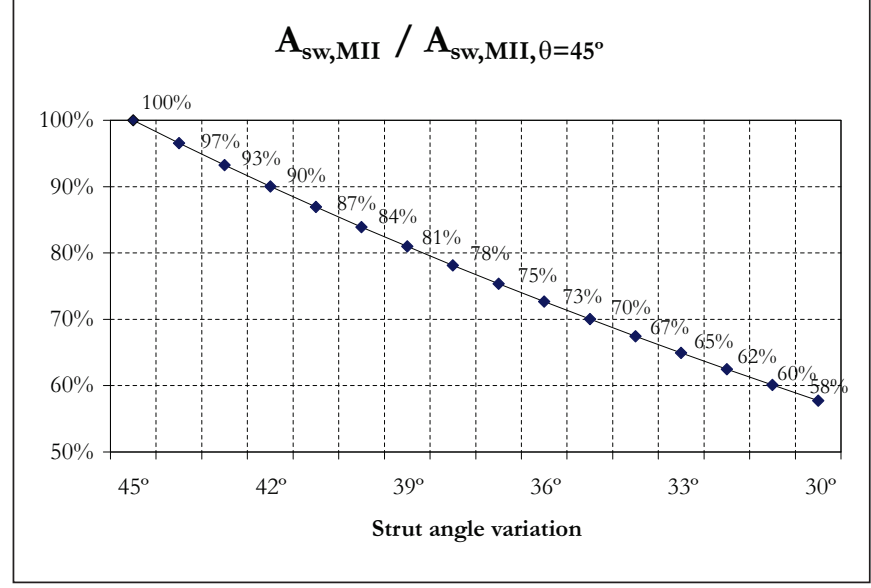

tained using calculation model II, the second compares the results of calculation model II to the results of calculation model I.

Due to the variation of the angle $\theta$ ranging from $30^{\circ}$ to $45^{\circ}$ in calculation model II, there is a reduction in the value of the reinforcement area calculated as the angle of inclination of the strut approaches $30^{\circ}$. It was also observed that, similar to the reduction of the design resistance, the relation between the areas of the transverse reinforcement obtained through calculation model II occurs due to the tangent of the angle $\theta$ relative to the compression strut, and is not influenced by geometry or by action effects in the structural element.

Arranging equation (8) for calculating $\mathrm{A}_{\mathrm{sw}}$ and considering stirrups inclined at $90^{\circ}$, one obtains the relation between the reinforcement areas of calculation model II and the reinforcement areas of the same model, with the angle of inclination of the strut equal to $45^{\circ}$. This relation is represented by equation (10) through which the graph of Figure 2 is obtained.

$$
\frac{\mathrm{A}_{\mathrm{sw}, \mathrm{MII}}}{\mathrm{A}_{\mathrm{sw}, \mathrm{MII}, \theta=45^{\circ}}}=\tan (\theta)
$$

The reduction of the reinforcement area is followed by the reduction of the design shear resistance on the ruin of the compression strut, $\left(V_{\mathrm{Rd} 2}\right)$. That is, when considering angle $\theta$ less than $45^{\circ}$, there is a penalty of the maximum value allowed for the design shear force, according to equation (7).

The comparison between the values obtained for the transverse reinforcement areas in calculation models I and II is difficult due to several parameters involved in the analysis. It is observed that for a given value of the design shear force $\left(V_{s d}\right)$, the portion of the shear force resisted by the transverse reinforcement $\left(\mathrm{V}_{\mathrm{sw}}\right)$ necessarily have distinct values in the two calculation models. This occurs because of different considerations that each calculation 
Table 1 - Percentage of transverse reinforcement area from calculation model I and II

\begin{tabular}{|c|c|c|c|c|c|c|c|}
\hline \multirow{2}{*}{$\begin{array}{l}\text { Força } \\
\text { Cortante }\end{array}$} & \multirow{2}{*}{$\begin{array}{l}\text { Ângulos } \\
\text { (graus) }\end{array}$} & \multicolumn{6}{|c|}{$\mathbf{A}_{\mathrm{sw}(\mathrm{M} /} / \mathbf{A}_{\mathrm{sw}(\mathrm{M})}(\%)$} \\
\hline & & $\mathrm{C} 25$ & C30 & C35 & $\mathrm{C} 40$ & $\mathrm{C} 45$ & C50 \\
\hline \multirow{6}{*}{$\begin{array}{l}20,40,60 \text { e } \\
80 \% \text { de } V_{\text {Rd2 }}\end{array}$} & $\Theta=45^{\circ}$ & 122 & 121 & 120 & 119 & 119 & 119 \\
\hline & $\Theta=42^{\circ}$ & 110 & 109 & 108 & 108 & 107 & 107 \\
\hline & $\theta=39^{\circ}$ & 99 & 98 & 98 & 97 & 97 & 97 \\
\hline & $\theta=36^{\circ}$ & 89 & 89 & 88 & 88 & 87 & 87 \\
\hline & $\Theta=33^{\circ}$ & 81 & 80 & 79 & 79 & 79 & 79 \\
\hline & $\theta=30^{\circ}$ & 73 & 72 & 71 & 71 & 71 & 71 \\
\hline
\end{tabular}

model used in relation to complementary mechanisms of the truss. As previously demonstrated, calculation model I considers a portion of constant reduction $\left(\mathrm{V}_{c 0}\right)$ given by equation (4). The reduction portion $\left(\mathrm{V}_{\mathrm{c} 1}\right)$ is variable in calculation model II, depending on the intensity of the design value of shear force $\left(V_{c 0}\right)$, according to equation (6). Another factor which influences this calculation is that in portion $\left(\mathrm{V}_{c 0}\right)$, the value of $\mathrm{f}_{\text {ctd }}$ is obtained according to the class of the concrete, that is, it depends directly on the value of the characteristic resistance to compression of the concrete, $f_{c k}$. Finally, the value of $\left(\mathrm{V}_{\mathrm{Rd} 2}\right)$ in calculation model II depends on the angle $\theta$ of

Figure 3 - Percentage reduction of transverse reinforcement area obtained form design models I and II in accordance with $\theta$ angle

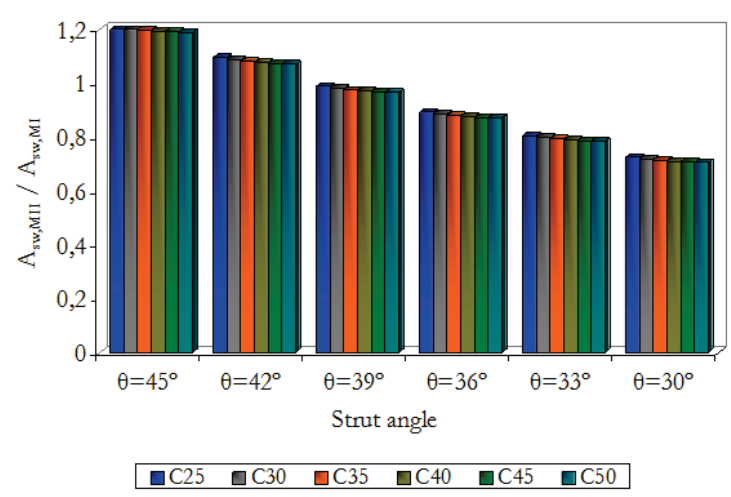

Shear force: $20 \%$ of $V_{\text {Rd2 }}$

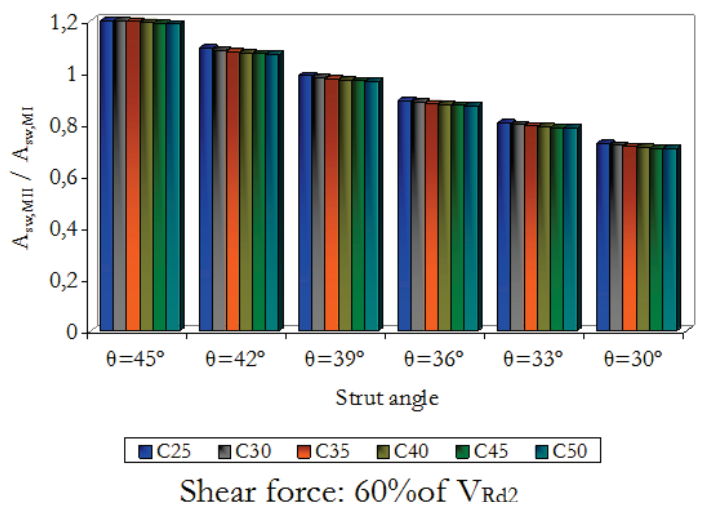

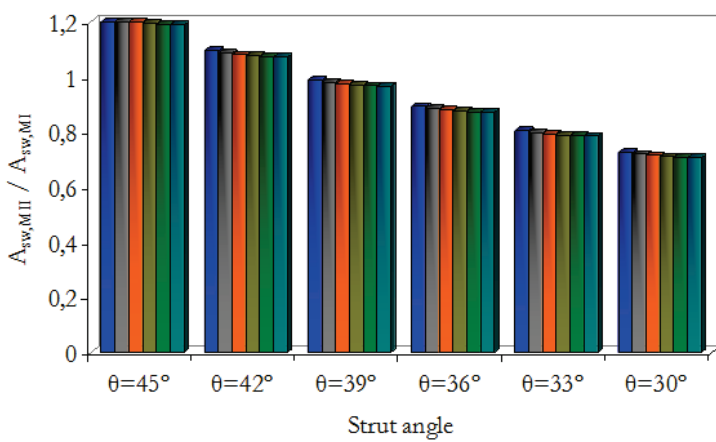

$\square \mathrm{C} 25 \quad \square \mathrm{C} 30 \quad \square \mathrm{C} 35 \quad \square \mathrm{C} 40 \quad \square \mathrm{C} 45 \quad \square \mathrm{C} 50$

Shear force: $40 \%$ of $\mathrm{V}_{\mathrm{Rd} 2}$

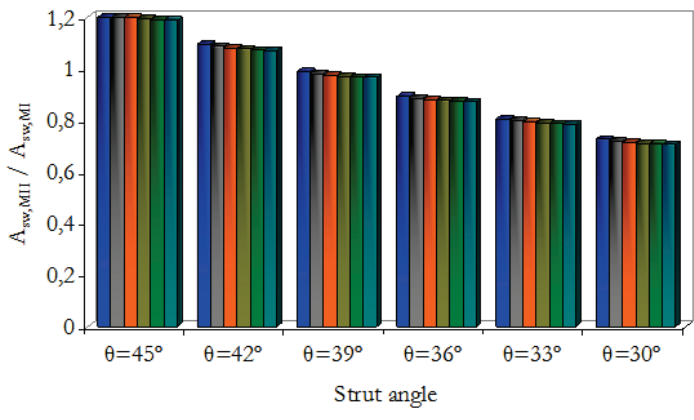

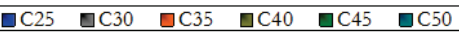

Shear force: $80 \%$ of $\mathrm{V}_{\mathrm{Rd}} 2$ 
inclination of the compression struts. Depending on the calculation model adopted, there are different values for the final length of the longitudinal reinforcement beam, due to the offset in the diagram of loads on the tensile chords, as shown in item 2. As the objective of this study is to consider only values of transverse reinforcement, the areas of longitudinal reinforcement bars were not considered. However, this consideration is important when comparing the total consumption of reinforcement in reinforced concrete beam.

Thus, the comparison between the areas of the transverse reinforcement utilizing calculation models I and II depends on three parameters previously described: the intensity of the design value of shear force, angle $\theta$ of inclination of the strut and the concrete class (which, according to the Brazilian Standard Code ABNT NBR 6118:2007 [1], can be C25, C30, C35, C40, C45 and C50).

Equation 11 shows the relation between the areas of the transverse reinforcement obtained according to calculation models I and II. In this expression, the portion $\mathrm{V}_{\mathrm{Rd} 2}$ refers to calculation model II and may be obtained through equation (7).

$\frac{A_{\mathrm{sw}, \mathrm{MII}}}{\mathrm{A}_{\mathrm{sw}, \mathrm{MI}}}=\left[\frac{\mathrm{V}_{\mathrm{Sd}}-\left(\frac{\mathrm{V}_{\mathrm{Rd} 2}-\mathrm{V}_{\mathrm{Sd}}}{\mathrm{V}_{\mathrm{Rd} 2}-\mathrm{V}_{\mathrm{c} 0}}\right) \cdot \mathrm{V}_{\mathrm{c} 0}}{\mathrm{~V}_{\mathrm{Sd}}-\mathrm{V}_{\mathrm{c} 0}}\right] \cdot \tan (\theta)$ (11)

The results obtained when calculating the area of the transverse reinforcement using calculation models I and II are presented. In order to facilitate the analysis of the results, the design value of shear force $\left(\mathrm{V}_{\mathrm{Sd}}\right)$ was defined as a percentage of the value of the design shear resistance $\left(\mathrm{V}_{\mathrm{Rd} 2}\right)$ in model II when considering the angle of inclination of the strut equal to $45^{\circ}$. Four percentages were used for calculating the design value of shear force: $20 \%, 40 \%$, $60 \%$ and $80 \%$ of the value of $\left(\mathrm{V}_{\mathrm{Rd} 2}\right)$. Thus, it is possible to separately observe the influence of the design value of shear force intensity and the concrete class on the process of obtaining the transverse reinforcement area. It is noted that, as the angle of inclination of the strut decreases from $45^{\circ}$ to $30^{\circ}$, there is a percentage reduction of the relation between the areas of the reinforcement obtained through calculation models II and I. According to the results obtained with calculation model I, the same value for the design shear resistance $\left(V_{\mathrm{Rd} 2}\right)$ is obtained when using calculation model II with an inclination angle of the strut equal to $45^{\circ}$, but with a larger area of the transverse reinforcement.

It is also stated that calculation model II always presents higher reinforcement than that obtained with calculation model I when using strut angles ranging from $40^{\circ}$ to $45^{\circ}$. When using the strut angle equal to $39^{\circ}$, the reinforcement area value obtained with model II results in the same obtained when using calculation model I. However, it presents a lower resistance capacity of the compression strut. For angle values ranging from $30^{\circ}$ to $38^{\circ}$, calculation model II leads to smaller values of the transverse reinforcement area, with minimum value when $\theta$ equals $30^{\circ}$.

For the same class of concrete, the reduction rate is not affected by the intensity of the action effects and remains constant for every design value of shear force $\left(\mathrm{V}_{\mathrm{sd}}\right)$, as shown in Table 1. However, it is observed that a change in the concrete class causes small mo- difications in the percentage of reduction. Comparing classes C25 and $\mathrm{C} 50$, the relation between the transverse reinforcement areas obtained through calculation model II and calculation model I with the strut angle of $45^{\circ}$ decreased from $122 \%$ to $119 \%$. Similarly, when considering the strut angle equal to $30^{\circ}$ for these classes, the ratio between the areas ranged from $73 \%$ to $71 \%$. The influence of the concrete class can be observed in the graphs of Figure 3.

\section{Linear elements subjected to torsion}

The Brazilian Standard Code ABNT NBR 6118:2007 [1] fixes conditions for the verification of reinforced concrete beam elements subjected to torsion combined with other structural loads, assuming a resistant model (space truss) which is defined based on a structural element with hollow section equivalent to the structural element to be calculated. That allows the angle $\theta$ of the inclination strut to have its value ranging from $30^{\circ}$ to $45^{\circ}$. But, it does not have two different calculation models such as the reinforced concrete beam elements subjected to shear force. The standard code requires the angles of the inclination strut to be the same for determining resistance when there is a combination of torsion and shear force.

Figure 4 shows the resultant forces in the reinforcement bars in a structural part submitted exclusively to torsion. The $R_{s \ell}$ force represents the results of tensile stresses in the longitudinal reinforcement bars distributed along the element section. The $R_{s 90}$ force is the resultant of tensile stresses on stirrups positioned at $90^{\circ}$ in relation to the part axis. The $R_{c w \text {.tor }}$ forces represent the resultant of the compression loads in the compressed struts.

Based on the results presented by Leonhardt \& Mönnig [3] and on the design of the space truss, the Brazilian standard Code ABNT NBR 6118:2007 [1] indicates a calculation model for reinforced concrete beam elements subjected to torsion. It is assumed that the transverse reinforcement have inclinations ranging from $45^{\circ}$ to $90^{\circ}$, and that the design torsion must be less than or equal to the resistance capacity of the compression strut $\left(T_{\mathrm{Rd} 2}\right)$, which is calculated through expression (12). In this expression, the value of $A_{e}$ represents the area delimited by the medium line of the wall of

\section{Figure 4 - Model of Section filled with simple torsion - Leonhardt \& Mönnig (3)}

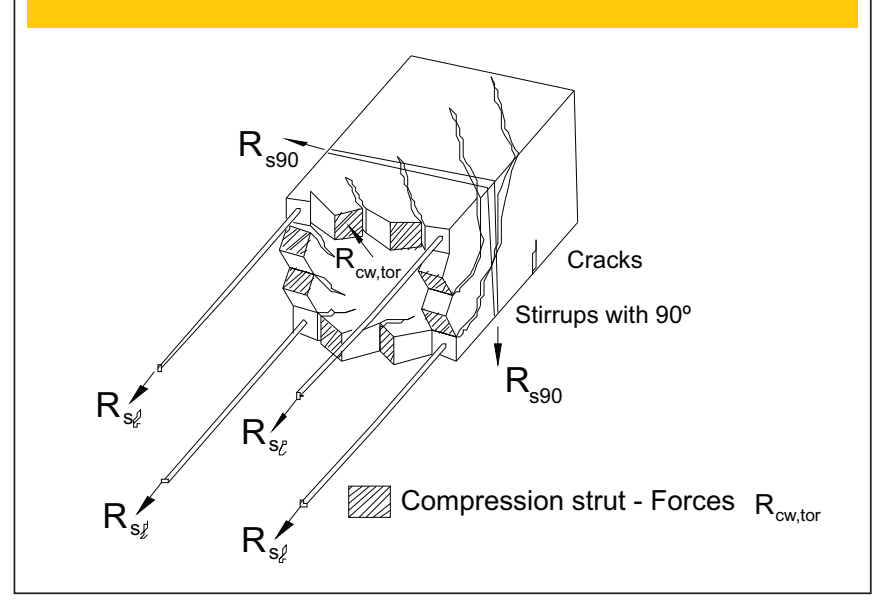


hollow section, and $h_{e}$ is the measurement of the thickness of the simulated wall.

$$
\mathrm{T}_{\mathrm{sd}} \leq \mathrm{T}_{\mathrm{Rd} 2}=0,50 \cdot\left(1-\mathrm{f}_{\mathrm{ck}} / 250\right) \cdot \mathrm{f}_{\mathrm{cd}} \cdot \mathrm{A}_{\mathrm{e}} \cdot \mathrm{h}_{\mathrm{e}} \cdot \operatorname{sen}(2 \theta)
$$

In addition to the verification of the compression strut, it is necessary to perform the verification of the transverse and longitudinal reinforcement resistance. In the case of transverse reinforcement, when they present angle a equal to $90^{\circ}$, the resistance condition is guaranteed by equation (13). In this equation, the value of $A_{90}$ represents the cross-sectional area of the number of branches of a stirrup, which must be in the region of the simulated wall. In relation to the longitudinal reinforcement, equation (14) must be used.

$$
\mathrm{T}_{\mathrm{sd}}=\mathrm{T}_{\mathrm{Rd}, 3}=\left(\frac{\mathrm{A}_{90}}{\mathrm{~s}}\right) \cdot \mathrm{f}_{\mathrm{ywd}} \cdot 2 \cdot \mathrm{A}_{\mathrm{e}} \cdot \cot \mathrm{g} \theta
$$

$$
\mathrm{T}_{\mathrm{sd}}=\mathrm{T}_{\mathrm{Rd}, 4}=\left(\frac{\mathrm{A}_{\mathrm{s} \ell}}{\mathrm{u}_{\mathrm{e}}}\right) \cdot \mathrm{f}_{\mathrm{ywd}} \cdot 2 \cdot \mathrm{A}_{\mathrm{e}} \cdot \operatorname{tg} \theta
$$

In equation (14), the term $u_{e}$ represents the perimeter of the area $A_{e}$. The torsion longitudinal reinforcement $A_{s e}$ may have the bars distributed along the perimeter or concentrated in the corners of the polygon that defines area $A_{e}$, in a necessarily constant ratio between the portion of the total calculated area $A_{s}$, and the portion of the perimeter of area $A_{e}$. Figure 5 presents a rectangular section of the reinforced concrete, in

\section{Figure 5 - Area $A_{e}$ in torsion design model}

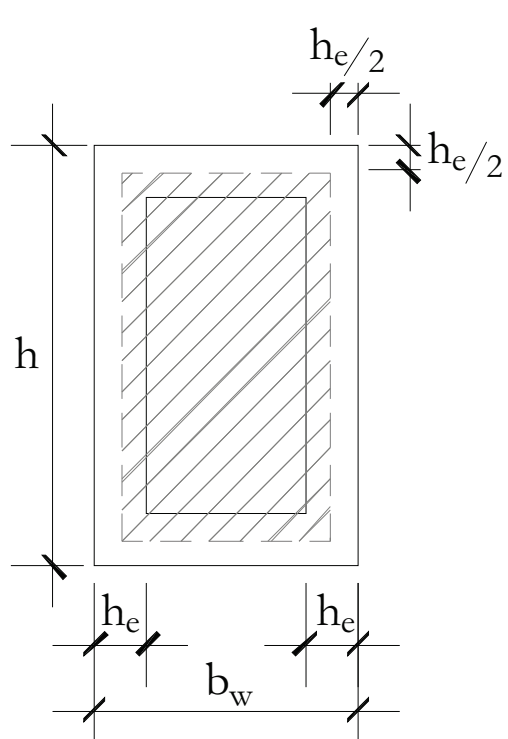

which the fictitious thickness according to thickness $h_{e}$ is delimited. Sin$c e b_{w}$ is the width and $h$ is the height of the section, the values of $A_{e}$ and $\mathrm{u}_{\mathrm{e}}$ and can be obtained through equations (15) and (16), respectively.

$$
A_{e}=\left(b_{w}-h_{e}\right) \cdot\left(h-h_{e}\right)
$$

$$
u_{e}=2 \cdot\left(b_{w}-h_{e}\right)+2 \cdot\left(h-h_{e}\right)
$$

\subsection{Torsion effects acting apart}

The possibility to vary the angle of inclination of the compression strut upon the occurrence of torsion in reinforced concrete beam elements enables an analysis similar to the one performed on item 3 in relation to shear force.

Regarding the analysis of the compression strut, the torsion resistance design $\mathrm{T}_{\mathrm{Rd} 2}$ presents a similar variation of the design shear resistance $\mathrm{V}_{\mathrm{Rd} 2}$. Taking the torsion resistance design with a $45^{\circ}$ angle as reference, there is a reduction of the strength capacity of the strut as the angle $\theta$ approaches $30^{\circ}$ according to equation (17). This result is consistent with the result obtained for the shear force, indicating that the relation between the strength capacity of the struts depends solely on the value of the inclination angle $\theta$ considered in the analyzes. The percentage ratio obtained through equation (17) is in Figure 6.

$$
\frac{\mathrm{T}_{\mathrm{Rd} 2}}{\mathrm{~T}_{\mathrm{Rd} 2, \theta=45^{\circ}}}=\operatorname{sen}(2 \theta)
$$

\section{Figure 6 - Relation between resistance torsion moment relative to compression strut TRd2, for several strut angles}

$$
\mathbf{T}_{\mathrm{Rd} 2} / \mathbf{T}_{\mathbf{R d} 2,>=45^{\circ}}
$$

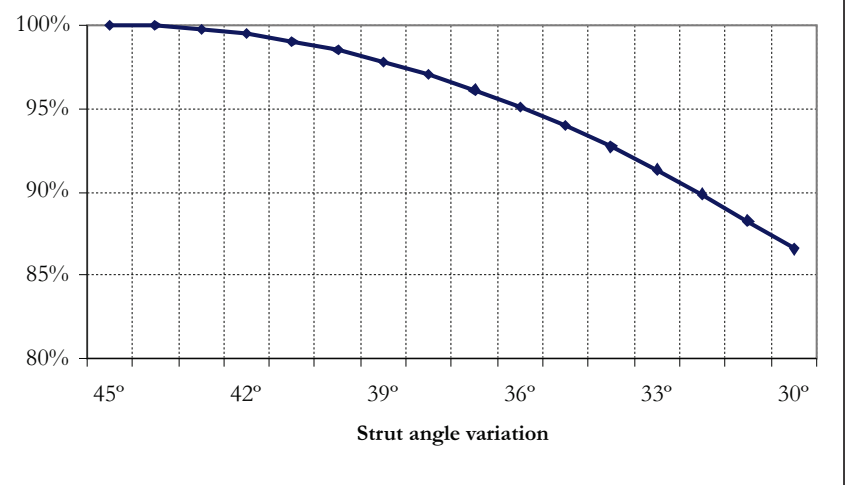




\section{Figure 7 - Percentage distribution of torsion reinforcement $A_{90} \in A_{s e}$}

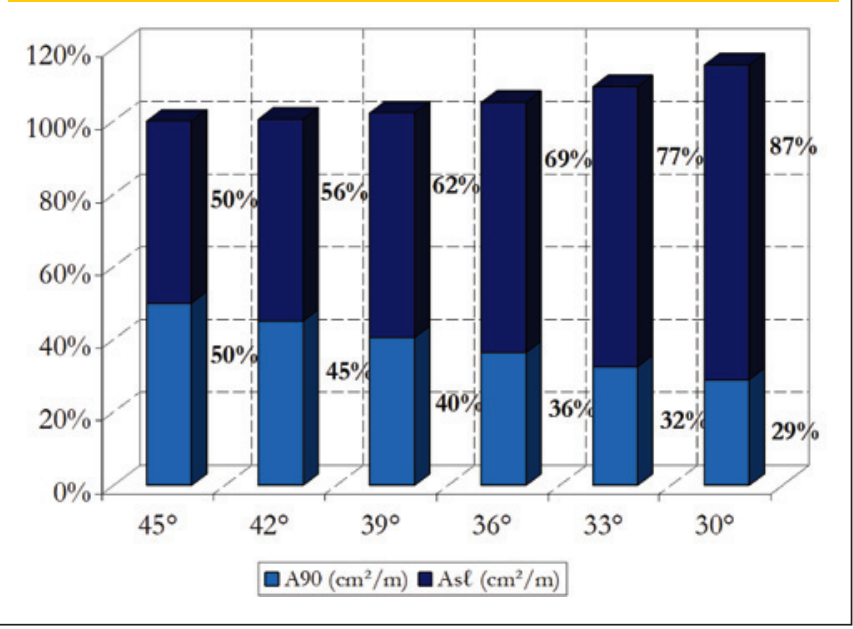

Similarly, it is observed that the relation between the areas of transverse and longitudinal reinforcement respectively defined by portions $T_{\mathrm{Rd} 3}$ and $\mathrm{T}_{\mathrm{Rd} 4}$ with variation of the inclination of the compression strut present a relation which depends exclusively on the angle of inclination of the strut. In the case of the transverse reinforcement, the relation between the areas $A_{90}$ depends on the tangent of the angle $\theta$, and for the longitudinal reinforcement, the relation between areas $A_{s \ell}$ vary according to the cotangent of the angle $\theta$.

Hence, it is possible to state that as the angle of the strut decreases from $45^{\circ}$ to $30^{\circ}$, there is a gradual decrease in the value of the transverse reinforcement area $A_{90}$ similar to that shown in Figure 2. By contrast, there is a significant increase in the longitudinal reinforcement area $\mathrm{A}_{\mathrm{s \ell}}$ as the strut angle approaches $30^{\circ}$. The greatest increase occurs when $\theta$ equals $30^{\circ}$, in which the longitudinal reinforcement area has a $173 \%$ higher value than the area obtained when angle $\theta$ equals $45^{\circ}$.

When analyzing the total reinforcement needed to resist torsion, that is, the combination of the areas obtained for $\mathrm{A}_{90}$ and $\mathrm{A}_{\mathrm{se}}$, one obtains relations between the areas that depend solely on the angle of inclination of the strut. The lowest amount of the total reinforcement is obtained when angle $\theta$ equals $45^{\circ}$, in which the areas of the longitudinal and transverse reinforcement have the same value. As the angle $\theta$ decreases, the increase of the longitudinal reinforcement $A_{s \ell}$ is higher than the reduction in the transverse reinforcement $A_{90}$, as observed in Figure 7. In this situation, there is an increase of $16 \%$ in relation to the total area obtained for an angle of $45^{\circ}$.

\subsection{Torsion and shear force effects combined}

When the structural element is subjected to the combined effects of torsion and shear force, some considerations must be made due to structural safety. The first relates to the adoption of equal inclination angles of the strut, which improves the safety analysis of the structural element related to torsion and shear force.

The use of the strut angle as less than $45^{\circ}$ to the space truss, which resists torsion, involves the use of model II for calculating the shear force. Only when the strut angle is $45^{\circ}$ there is the option of adopting calculation model I to resist the effects of shear. In this situation, calculation model II could also be used. However, as shown in item 3 , this consideration leads to elevated values of transverse reinforcement area because of the shear force.

Another consideration relates to the verification of the strength capacity of the compression strut. In this case, independently of the strut angle and the calculation model considered for the analysis, it is necessary to attend to the condition expressed in equation (18). This condition considers the percentage that each action effect requires to resist the compression strut. It must not exceed $100 \%$ because as it approaches the mentioned ratio, there is a greater chance of ruining the structural element due to rupture of the compression strut.

$$
\frac{\mathrm{V}_{\mathrm{sd}}}{\mathrm{V}_{\mathrm{Rd} 2}}+\frac{\mathrm{T}_{\mathrm{sd}}}{\mathrm{T}_{\mathrm{Rd} 2}} \leq 1
$$

Regarding the reinforcement area, the principle of superposition of effects is accepted. That is, the total transverse reinforcement is given by the sum of the separately design reinforcement for effects of torsion and shear force, through the portions of $A_{90}$ and $A_{s w}$. The lateral reinforcement $A_{s e}$ is only calculated if torsion occurs, and it may be distributed along the equivalent perimeter of the concrete section, or displayed in the vertices of the section.

As the angle of inclination of the strut varies from $45^{\circ}$ to $30^{\circ}$, the value of the total transverse reinforcement decreases in order that both $A_{s w}$ and $A_{90}$ portions also decrease. Thus, the total transverse reinforcement has its maximum value if calculation model II is considered, for the shear force, with a $45^{\circ}$ angle, and has its minimum value if the same model is considered, although with an inclination angle of the strut equal to $30^{\circ}$. The use of calculation model I provides intermediate values for the total transverse reinforcement. Figure 8 presents the area of total transverse reinforcement in relation to calculation model I.

\section{Figure 8 - Total transverse reinforcement $A_{90}$ e $A_{s w}$ in relation to reinforcement area from calculation model I}

Total transverse reinforcement

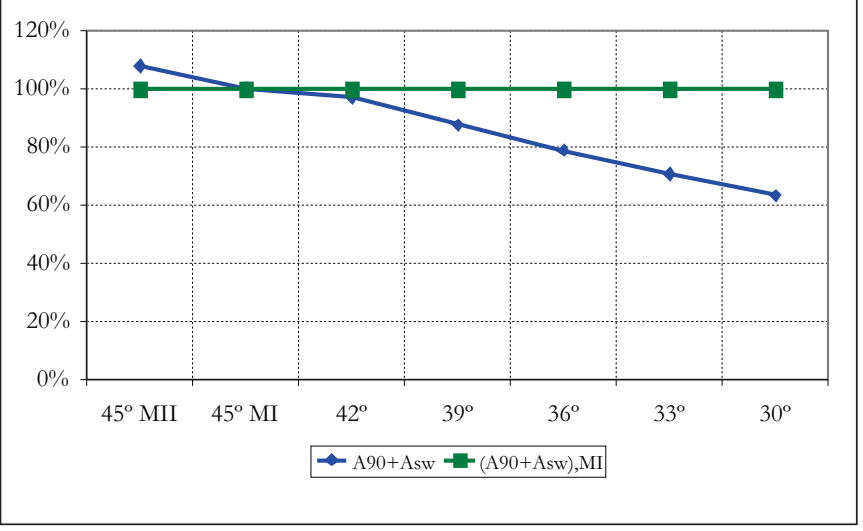




\section{Figure 9 - Total reinforcement $A 90, A_{s w}$ e $A_{s e}$ in relation to reinforcement area from calculation model I}

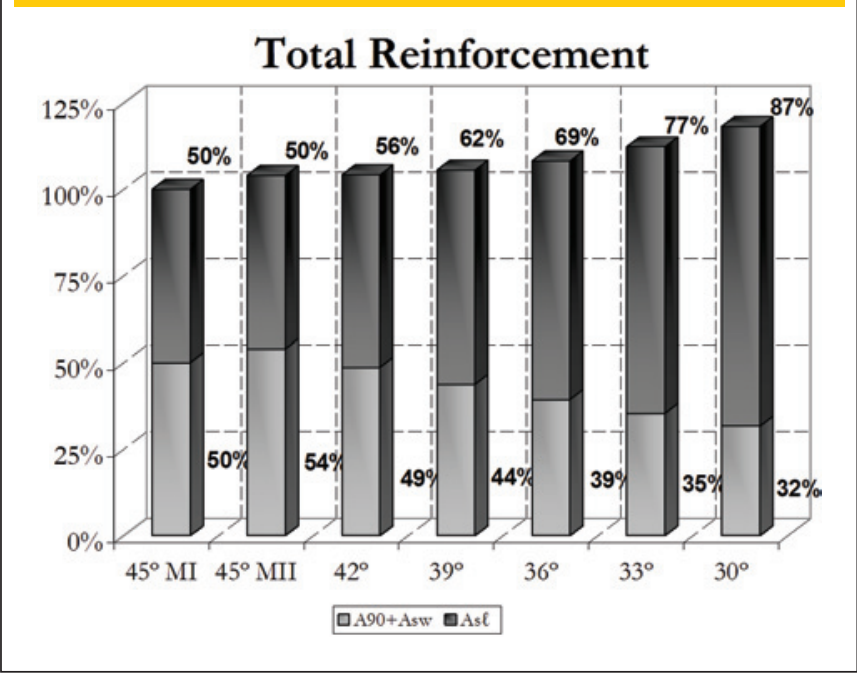

At first, the graph in Figure 8 induces the reader to believe that the situation in which greater reinforcement saving is obtained is the consideration of calculation model II with the strut angle equal to $30^{\circ}$. However, this conclusion is mistaken due to the existence of the torsion longitudinal reinforcement $\mathrm{A}_{\mathrm{s} \ell}$ and offset of tensile chord loads diagram, which was not considered in this study. This reinforcement shows higher values as the angle of inclination of the strut approaches $30^{\circ}$, as shown in Section 4.1. This reinforcement has to be considered in the total reinforcement design, and then it is possible to compare calculation models to state which leads to a lower consumption of the total reinforcement.

Therefore, the use of calculation model I leads to greater steel savings when compared to alternatives in calculation model II for considering angle $\theta$ of inclination of the strut. Figure 9 shows the percentage distribution of total transverse reinforcement, $A_{90}$ and $A_{s w}$, and torsion longitudinal reinforcement $A_{s e}$ in relation to the values obtained using calculation model $\mathrm{I}$. It is observed that when using calculation model II with strut angle as $30^{\circ}$, the total reinforcement presents itself $19 \%$ greater than that obtained with calculation model I. This situation occurs because most of the total reinforcement area is represented by the torsion longitudinal reinforcement $A_{s ?}$

\section{Conclusion}

The analysis of the results of transverse reinforcement areas design, derived from the isolated action of shear force and torsion as well as the combined action of these action effects, were presented. To perform the analysis, vertical stirrups placed at $90^{\circ}$ were considered. Considering the isolated action of the shear force, the main conclusions are:

- Calculation model I leads to high values of the transverse reinforcement area compared with calculation model II, when using the strut angle inclined between $30^{\circ}$ and $39^{\circ}$. These results are justified by the fact that calculation model I is a simplification of calculation model II, therefore, it tends to be more conservative when considering solely the values of the transverse reinforcement, and not the offset of tensile chord loads diagram effect.

- In calculation model II, when the strut angle is $45^{\circ}$, one obtains the same value for design shear resistance $\mathrm{V}_{\mathrm{Rd} 2}$ in model $\mathrm{I}$, but with a greater transverse reinforcement area. If the strut angle ranges from $40^{\circ}$ to $45^{\circ}$, there is a reduction of the values of $\mathrm{V}_{\mathrm{Rd}, 2}$ and $\mathrm{A}_{\mathrm{sw}}$, but the reinforcement area remains greater than the one obtained with calculation model I.

- Based on the results presented, it is not justifiable to use calculation model II with the strut angle ranging from $40^{\circ}$ to $45^{\circ}$.

- The adoption of the inclination angle of the strut equal to $39^{\circ}$ in calculation model II results in the same area of transverse reinforcement obtained when using calculation model I, but with less strength capacity of the strut.

- Comparing the results of reinforcement area in calculation model II in relation to calculation model I, it is observed that the intensity of the action effects have little influence in the reduction percentage of the transverse reinforcement area. However, there is little variation in this percentage due to the class of concrete considered in the design stage.

Regarding the isolated effects of torsion and the combined effects of torsion and shear force, the following conclusions are presented:

- The portions of the compression strut, $\mathrm{V}_{\mathrm{Rd} 2}$ and $\mathrm{T}_{\mathrm{Rd} 2}$, have equivalent reduction as the angle of inclination of the strut decreases compared with the $45^{\circ}$ angle.

- Regarding the areas of the transverse and longitudinal reinforcement bars derived from the combined action of torsion and shear force, it appears that as the angle of the strut decreases from $45^{\circ}$ to $30^{\circ}$, there is a reduction of the transverse reinforcement torsion $A_{90}$, an increase in the longitudinal reinforcement torsion $\mathrm{A}_{\mathrm{s} \text {, }}$ and a reduction of the transverse reinforcement due to shear force, $A_{s w}$

- Regarding the percentage distribution of the total transverse reinforcement area $\left(A_{90}\right.$ and $\left.A_{s w}\right)$, there is a reduction in the value of the reinforcement areas as the angle $\theta$ of the strut decreases. For angles of inclination of the strut close to $30^{\circ}$, this reduction is of approximately $63 \%$ in relation to the total area obtained when the angle is $45^{\circ}$.

- Concerning the percentage distribution of the total reinforcement area $\left(A_{90}, A_{s w}\right.$ and $\left.A_{s e}\right)$, there is an increase in the final value of the reinforcement areas as the angle $\theta$ of the strut decreases, resulting in an approximate 19\% increase with angles $\theta$ close to $30^{\circ}$, compared to the total area obtained when considering angle $\theta$ equal to $45^{\circ}$.

- The use of calculation model I for shear force combined with the effects of torsion leads to greater steel savings when compared to calculation model II.

Finally, it is emphasized that high values of shear force often occur in transition beams, and usually show high values of bending moment, which can compromise the design of the longitudinal bars of the beam. For a beam to present deformations in field 3 , it is recommended that the design value of shear force does not exceed $40 \%$ of the strength capacity value of the compression strut.

\section{Acknowledgements}

The authors thank the Department of Structural Engineering of Sao Carlos Engineering School, Universidade de São Paulo, CA$\mathrm{PES}$ and CNPq for the PhD scholarship of the first author. 


\section{References}

[01] BRAZILIAN ASSOCIATION OF TECHNICAL STANDARDS. NBR 6118 - Design of concrete structures - Procedure. Rio de Janeiro, ABNT. 2007

[02] MÖRSCH, E. Teoría y práctica del hormigón armado, versión del alemán, Editorial Gustavo GILI, S.A. Barcelona, Tomo II, 1948, $476 \mathrm{p}$.

[03] LEONHARDT, F., MÖNNIG, E. Vorlesungen uber massivbau, Berlin:. Springer-Verlag, 1973.(Portuguese version: Construções de concreto - Ed. Interciência. V.3, 1.ed. Rio de Janeiro, 1977).

[04] MOTA, J, E.; LARANJEIRAS, A. C. R. (2002). Força Cortante - NB1 - Perguntas e Respostas -Lista de discussão eletrônica, comunidade calculistas-ba. Disponível em: <http://br.groups.yahoo.com/group/ calculistas-ba/message/1839?threaded=1\&l=1> Acessos em: 16 set. 2002.

[05] SAVARIS, G., GARCIA, S. L. G. Determination of the optimum strut and tie angle for designing of beams submitted to simple bending using the directions of the brazilian standard NBR 6118:2003. Proceedings of 49th Brazilian Concrete Conference, CBC-2007, Bento Gonçalves-RS, 2007.

[06] BARROS, R., GIONGO, J. S. Area Calculation of Transverse Reinforcement in Linear Reinforced Concrete Elements Submitted to Shear Force: Comparative Analysis Based in Models I and II of Brazilian Standard NBR 6118:. Proceedings of 50th Brazilian Concrete Conference, CBC-2008, Salvador-BA, 2008.

[07] COMITE EURO-INTERNACIONAL DU BÉTON. CEB-FIP Model code for concrete structures. Bulletin D'Information, Paris, n. 203-205, July, 1990

[08] MANGINI, S. Força Cortante - Elementos lineares com armaduras transversais. Os princípios diretivos da proposta do texto de revisão da NB 1. IV Simpósio EPUSP sobre Estruturas de Concreto. São Paulo-SP, 2000. 